\title{
Pengembangan UMKM dalam Meningkatkan Kesejahteraan Masyarakat di Wilayah Pedesaan
}

Oleh:

*) Yuli Rahmini Suci, S.E., M.M.

**) Dosen Sekolah Tinggi Ilmu Ekonomi Balikpapan

\begin{abstract}
Abstrak
Pengembangan Usaha Mikro Kecil dan Menengah Merupakan suatu kegiatan yang sangat dibutuhkan dalam memajuakan dan mensejahtrakan masyakat. Ini merupakan agenda pemerintah dalam percepatan pemulihan ekonomi dan memeperkuat landasan pembangunan berkelanjutan dan keadilan diwujudkan melalui pengembangan sistem ekonomi kerakyatan berdasarkan keadilan dengan tetap memperhatikan pemanfaatan sumber daya manusia yang optimal dan pelestarian wirausaha mandiri. Reformasi Pemerintahan di Tingkat wilayah Desa dibutuhkan kehandalan dalam menciptakan suatu kebijakan yang bisa menciptakan hal baru untuk mendukung kebijakan pusat yaitu menyejahtrakan rakyat. UMKM merupakan solusi yang jitu dipersipakan oleh pemerintah sebagai usaha untuk membuka lapangan kerja dan meyerap tenaga kerja. Kecerdasan intelektural dan kedewasaan seorang pemimpin Desa diharapkan mampu membangun dan mengembangkan wilayah Desa melalui program UMKM yang telah digariskan oleh pemerintah dalam mengentaskan kemiskinan dan menurunkan pengangguran atau penyerapan tenaga kerja.
\end{abstract}

Kata Kunci: Pemerintah, Kebijakan, UMKM, dan Pemimpin

\begin{abstract}
Development of Micro, Small and Medium It is an activity that is needed in memajuakan and mensejahtrakan society. This is a government agenda to accelerate the economic recovery and sustainable development foundation memeperkuat and justice realized through the development of a democratic economic system based on justice with regard to the utilization of human resources and the optimal preservation of independent entrepreneurs. Government Reform in Village area required level of reliability in creating a policy that could create new things to support policies that center menyejahtrakan people. SMEs a workable solution prepared by the government in an effort to create jobs and absorb labor. Intelektural intelligence and maturity of a village leader is expected to build and develop the Village area through MSME program which has been outlined by the government in alleviating poverty and reducing unemployment or employment.
\end{abstract}

Keywords: Government, Policy, SMEs, and Leaders 


\section{Pendahuluan}

Setelah melalui berbagai probelmatika domestik pasca kemerdekaan, pertumbuhan ekonomi indonesia baru melaju relatif cepat mulai tahun 1968. Pada kurun waktu 1968-1982 tercatat rata-rata pertumbuhan ekonomi Indonesia sekitara 7,65\% pertahun. Pertumbuhan ekonomi yang relatif tinggi selama kurun waktu tersebut ternyata belum sepenuhnya membuat kokoh stabilitas prekonomian nasional. Terjadinya external shocks yang dimulai dengan OPEC Oil Price Shock II di awal dekade 1980-an kurang lebih tepatnya pada tahun 1979 sampai 1980 menyebabkan rentan pertumbuhan ekonomi Indonesia yang kala itu masih ditopang oleh ekspor migas turun menjadi sekitar 4,5\% pertahun pada dekade tersbut. Perekonomia Indonesia baru bisa pulih dari dampak negatif goncangan atau shock minyak bumi mulai penghujung dekade 1980-an, dan mencatat rentan pertumbuhan ekonomi sekitar 7\% pertahun selama kurun waktu 1989-1993. Selanjutnya pada priode 1994-1996 tercatat rata-rata pertumbuhan ekonomi Indonesia mengingkat lagi menjadi 7,9\% pertahun. Dinamika pertumbuhan ekonomi Indonesia mendapatkan ujian hebat pada pertengahan tahun 1997. Pondasi ekonomi Indonesia yang sudah dibangun sekian tahun lamanya mengalami guncangan hebat yaitu krisis ekonomi yang diawali dengan krisis moneter. Krisis ini telah memporak-porandakan perekonomian Indonesia.

Pertumbuhan ekonomi yang tinggi terkontraksi hingga hanya mencapai angka pertumbuhan sebesar $4,7 \%$ pada tahun tersebut. Kemudian merosot terjun bebas hingga sekitar $-13,1 \%$ pada tahun 1998, ini merupakan catatan terburuk dalam sejarah prekonomian di Indoensia. Krisis ini juga berimbas kepada Indikator makro lainnya seperti inflasi yang meningkat hingga mencapai angka 78\%. Tingginya inflasi ini menyebabkan tingkat harga terutama harga barang kebutuhan pokok melonjak tinggi. Situasi ini semakin memperparah kemiskinan yang pada masa sebelumnya nilainya tidak begitu berarti. Sementara itu, tingkat pengangguran juga meningkat signifikan akibat semakin minimnya lapangan pekerjaan dan PHK besar-besaran disektor industri besar nasional yang berhenti beroprasi karena tingginya biaya produksi akibat depresiasi nilai tukar rupiah terhadap mata uang asing atau dalam hal ini mata Uang Dollar.

Secara perlahan, Indonesia mulai dari keterpurukan walaupun masih menyisahkan permasalah ekonomi yang mendasar yaitu stagnasi pertumbuhan ekonomi dimasa pasca krisis. Pada tahun 1999 pertumbuhan Indonesia kembali berdenyut pada tingkat pertumbuhan positif sebesar $0,79 \%$ dan terus mengalami peningkatan lagi pada tahun-tahun 
berikutnyan.Pada Priode 1999 hingga tahun 2003 rentan pertumbuhan ekonomi Indonesia tercatat sebesar 3,7\%. Selanjutnya pada priode 2004 hingga 2006 angka pertumbuhan ekonomi Indoensia dengan rentan mencapai 5,4\%. Namun secara umum, tren pertumbuhan ekonominya sebenarnya kembali seperti masa sebelum krisis.

Pertumbuhan ekonomi yang lambat pulih tersebut diiringi dengan jumlah penduduk miskin yang cenderung meningkat. Walaupun laju pertumbuhan ekonomi triwulan 2006 sudah mencapai $6,1 \%$, namun hal tersebut belum secara nyata dapat mengurangi jumlah penduduk miskin. Teori ekonomi menyatakan bahwa pertumbuhan ekonomi, yang menunjukan semakin banyak output nasional, mengindikasikan semakin banyaknya orang yang bekerja, sehingga akan mengurangi pengangguran dan tingkat kemiskinan akan menurun ${ }^{2}$.

Pada saat krisis ekonomi melanda dan pasca krisis pengembangan industri mendapatkan tantangan semakin besar dengan semakin kuatnya gelombang globalisasi yang sulit dihadapi. Kebijakan Pemerintah tidak lagi mengandalkan ekspor migas setalah melihat bahwa saat krisis sektor ini terkena imbasnya. Disinilah peran penting yang dimaikan oleh UMKM dalam meningkatkan perekonomian Nasioanal karena kemampuannya menciptakan lapangan kerja secara cukup signifikan.

Sektor UMKM memang lebih bersifat padat karya. Peran ini tentu saja akan sangat bernilai strategis manakala masalah ini di konfrontir dengan persoalan besar yang tak kunjung dapat teratasi di atasi oleh pemerintah, yaitu penganguran dan kemiskinan.

Dengan kata lain ada upaya yang dilakukan pemerintah dengan serius untuk mengembangkan sektor UMKM. Harapan dari pemerintah bahwa masalah mendasar seperti pengangguran dan kemiskinan bisa terselesaikan walaupun tidak dalam jangka waktu singkat namun minimal bisa menurunkan hal tersebut dimasa mendatang.

Berdasarkan gambaran fenomena diatas, maka timbul satu permasalah yang sangat selalu sulit dipecahkan yang mengakibatkan siklus timbul tengelamnya UMKM-UMKM diantarnaya kurang modal atau terbatasnya akses pembiyaan, kualitas Sumber Daya Manusia dan lemahnya manajeman yang mengakibatkan tidak transparan, minimnya jaringan dalam pemasaran produk, dan mentalitas menghadapi tantangan dalam berwiraswasta atau Enterpenuer.

2 Hermanto Siregar, dan Dwi Wahyuniarti.DAMPAK PERTUMBUHAN EKONOMI TERHADAP PENURUNAN JUMLAH PENDUDUK MISKIN.ARTIKEL EKONOMI LINGKUNGAN IPB,HAL:23-40, 2008 
Melihat permasalahan yang dihadapi UMKM perlu suatu solusi yang jitu yang harus diambil oleh Pemerintah khusunya Pemerintah Desa yang menjadi kepanjang tangganan Pemerintah Pusat yang harus bergerak cepat untuk dapat melahirkan program-program pembanguna yang dapat menolong UMKM tersebut dari keterpurukan. Sebab UMKM hampir rata-rata berada di tingkat wilayah desa atau kelurahan.

\section{Data dan Fakta}

Menurut Badan Pusat Statistik(BPS) kontibusi UMKM terhadap PDRB tampa sektor migas pada tahun 2010 tercatat mencapai 62,71\% dan pada tahun 2011 meningkat kontribusinya mencapai $63,89 \%^{3}$.

UMKM memiliki peran yang cukup besar dalam pembangunan ekonomi Nasional, hal ini terlihat dari kontribusinya terhadap PDB Indonesia yang terus meningkat setiap tahunnya.Perbandingan PDB menurut kelompok usaha pada tahun 2010 hingga 2011 tersaji pada tabel berikut:

Tabel 1. Perbandingan Komposisi PDB Menurut Usaha pada Tahun 2010-2011

\begin{tabular}{|c|c|c|c|}
\hline Skala Usaha & 2010 & 2011 & Pertumbuhan(\%) \\
\hline UMKM & 433,245 & 444,453 & $+2,59 \%$ \\
\hline
\end{tabular}

Sumber :BPs dan Kementrian Koperasi\&UKM (diolah)

Pada awal Tahun 2012 jumlah tenaga kerja yang diserap oleh sektor UMKM tercatat mencapai 80juta orang. ini merupaka suatu hal yang sangat baik disaat kondisi perekonomian dalam menghadapi permasalah penganguran dan kemiskinan. Disadari akan begitu besarnya peran UMKM dalam perekonomian Nasioanl, maka perlu adanya perhatian khusus guna mendorong pengembangan kemajuan dan peningkatan UMKM. Pendekatan pemberdayaan usaha merupakan salah satu solusi yang bisa diambil oleh pemerintah melalui aspek sosial budaya di masing-masing wilayah khususnya desa-desa di Indonesia, sebab UMKM biasanya berada di daerah pedasaan atau dekat dengan sumber daya dari masyarakat langsung ${ }^{4}$.

Berdasarkan hal tersebut Pemerintah memberi perhatian yang sangat besar terhadap perkembangan Usaha Mikro Kecil Dan Menengah (UMKM). Tidak saja jumlah UMKM di

\footnotetext{
${ }^{3}$ Data BPS Indonesia dalam angka 2010-2011.

${ }^{4}$ Bachtiar Rifa'i.EFEKTIVITAS PEMBERDAYAAN USAHA MIKRO KECIL DAN MENENGAH(UMKM)KRUPUK IKAN DALAM PROGRAM PENGEMBANGAN LABSITE PEMBERDAYAAN MASYARAKAT DESA KEDUNG REJO KECAMATAN JABON KABUPATEN SIDOARJO.Jurnal Kebijakan dan Manajemen Publik.Vol.1,No(1),Hal:130-136,2013.
} 
Indonesia mendominasi, tetapi juga UMKM dapat lebih bertahan dari terpaan krisis global.Berbagai inisiatif selalu diusahakan oleh pemerintah melalui pemerintah melalui Kementerian Negara Koperasi dan Usaha Kecil Menengah agar semakin banyak individu mau menekuni dunia wirausaha dalam bentuk pendirian UMKM.Perhatian pemerintah terhadap UMKM yang sangat besar merupakan langkah strategis yang tepat dibutuhkan bangsa Indonesia. Keseriusan kepedulian pemerintah terhadap UMKM dengan programprogram untuk menumbuh kembangkan UMKM di Indonesia. Meskipun dukungan pemerintah Indonesia sangat besar untuk menjadikan UMKM (Usaha Mikro Kecil dan Menengah) berhasil dan berkembang bukan berarti tanpa kendala.

Agenda percepatan pemulihan ekonomi dan memeperkuat landasan pembangunan berkelanjutan dan keadilan diwujudkan melalui pengembangan sistem ekonomi kerakyatan berdasarkan keadilan dengan tetap memperhatikan pemanfaatan sumber daya manusia yang optimal dan pelestarian wirausaha mandiri. Pembangunan ekonomi nasional bukan hanya tanggung jawab pemerintah, namun merupakan tanggung jawab bersama. Masyarakat adalah pelaku utama pembangunan dan pemerintah punya andil besar dalam hal untuk dapat mengarahkan, membimbing dan menciptakan fasilitas penunjang. Semakin sempitnya lapangan kerja merupakan penyelesaian yang tidak bisa ditunda-tunda lagi, karena penduduk merupakan aset berharga bagi bangsa dan negara. Pertumbuhan masyarakat visual mandiri merupakan alternatif jitu untuk memecahnya ${ }^{5}$.

\section{Keunggulan UMKM}

Usaha mikro, kecil dan menengah (UMKM) di Indonesia sangat penting karena karakteristik utama mereka yang membedakan kelompok usaha ini dengan usaha besar (UB),yakni sebagai berikut (Tambunan, 2012a):

Pertama,jumlah perusahaan sangat banyak (jauh melebihi jumlah UB), terutama dari kategori usaha mikro (UMI) dan usaha kecil (UK). Berbeda dengan UB dan UM(usaha menengah), UMI dan UK tersebar di seluruh pelosok perdesaan, termasuk di wilayahwilayah yang relatif terisolasi.Oleh karena itu kelompok usaha ini yang khusus untuk

\footnotetext{
5 Endang Purwanti.PENGARUH KARAKTERISTIK WIRAUSAHA, MODAL USAHA, STRATEGI PEMASARAN TERHADAP PERKEMBANGAN UMKM DI DESA DAYAAN DAN KALILONDO SALATIGA.(Jurnal Among Makarti.Vol.5.No(9).Hal:13-28, 2012).
} 
ekonomi perdesaan.Dengan kata lain, kemajuan pembangunan ekonomi perdesaan sangat ditentukan oleh kemajuan pembangunan UMKM-nya;

Kedua, karena sangat padat karya, yang berarti mempunyai suatu potensi pertumbuhan kesempatan kerja yang sangat besar,pertumbuhan UMKM dapat dimasukkan sebagai suatu elemen penting dari kebijakan-kebijakan nasional untuk meningkatkan kesempatan kerja dan menciptakan pendapatan, terutama bagi masyarakat miskin. Hal ini juga yang bisa menjelaskan kenapa pertumbuhan UMKM menjadi semakin penting di perdesaan,terutama di daerah-daerah di mana sektor pertanian mengalami stagnasi atau sudah tidak mampu lagi menyerap pertumbuhan tahunan dari penawaran tenaga kerja di perdesaan. Sesuai teori dari A. Lewis (suplai tenaga kerja tak terbatas), kondisi kelebihan tenaga kerja di perdesaan akan menciptakan arus manusia terus menerus dari perdesaan ke perkotaan. Apabila kegiatankegiatan ekonomi perkotaan tidak mampu menyerap pendatang-pendatang tersebut,jumlah pengangguran akan meningkat,dan akan muncul banyak masalah sosial terkaitnya di perkotaan.Oleh sebab itu, kegiatan-kegiatan nonpertanian di perdesaan, terutama industri,selalu diharapkan bisa berfungsi sebagai sumber penyerapan kelebihan penawaran tenaga kerja ke sektor pertanian, sehingga bisa membatasi arus migrasi ke perkotaan;dan dalam hal ini, UMKM di perdesaan dapat memainkan suatu peran krusial;

Ketiga,tidak hanya mayoritas dari UMKM,terutama UMI, berlokasi di perdesaan,namun kegiatan-kegiatan produksi dari kelompok usaha ini juga pada umumnya berbasis pertanian. Oleh karena itu, upayaupaya pemerintah mendukung UMKM sekaligus juga merupakan suatu cara tak langsung namun efektif untuk mendukung pembangunan dan pertumbuhan produksi di sektor pertanian;

Keempat,UMKM memakai teknologi-teknologi yang lebih "cocok" (jika dibandingkan dengan teknologi-teknologi canggih yang umum dipakai oleh perusahaanperusahaan modern/UB) terhadap proporsi-proporsi dari faktor-faktor produksi dan kondisi lokal yang ada di Indonesia, yakni sumber daya alam (SDA) dan tenaga kerja berpendidikan rendah yang berlimpah (walaupun jumlahnya bervariasi menurut negara atau wilayah didalam sebuah negara, tetapi modal serta sumber daya manusia (SDM), atau tenaga kerja berpendidikan tinggi) yang sangat terbatas;

Kelima, banyak UMKM bisa tumbuh pesat. Bahkan banyak UMKM bisa bertahan pada saat ekonomi Indonesia dilanda suatu krisis besar pada tahun 1997/98 yang dikenal dengan krisis keuangan Asia. Oleh sebab itu, kelompok usaha ini dianggap sebagai perusahaan- 
perusahaan yang memiliki fungsi sebagai basis bagi perkembangan usaha lebih besar. Misalnya UMI bisa menjadi landasan bagi pengembangan UK,sedangkan UK bagi UM, dan UM bagi UB;

Keenam, walaupun pada umumnya masyarakat perdesaan miskin, banyak bukti yang menunjukkan bahwa orang-orang desa yang miskin bisa menabung, dan mereka mau mengambil risiko dengan melakukan investasi. Dalam hal ini, UMKM bisa menjadi suatu titik permulaan bagi mobilisasi tabungan/investasi diperdesaan; sementara, pada waktu yang sama, kelompok usaha ini dapat berfungsi sebagai tempat pengujian dan peningkatan kemampuan berwirausaha dari orangorang desa;

Ketujuh, masih berkaitan dengan butir 6, terbukti bahwa pada umumnya pengusahapengusaha UMKM membiayai sebagian besar dari operasi-operasi bisnis mereka dengan tabungan pribadi, ditambah dengan bantuan atau pinjaman dari saudara atau kerabat, atau dari pemberipemberi kredit informal, pedagang atau pengumpul, pemasok-pemasok bahan baku, dan pembayaran di muka dari konsumen-konsumen. Oleh karena itu,kelompok usaha ini dapat memainkan suatu peran penting lainnya, yaitu sebagai suatu alat untuk mengalokasikan tabungan-tabungan perdesaan, yang kalau tidak, akan digunakan untuk maksudmaksud yang tidak produktif. Dengan kata lain, jika kegiatan-kegiatan produktif tidak ada di perdesaan, keluarga-keluarga perdesaan yang memiliki uang lebih akan menyimpannya di dalam rumah yang tentu tidak akan menghasilkan nilai tambah dalam bentuk penghasilan dari bunga tabungan, karena di banyak desa belum ada bank, atau menggunakannya untuk tujuantujuan konsumtif seperti beli tanah, mobil atau rumah, atau barang-barang konsumsi mewah lainnya yang sering dilihat oleh warga desa sebagai sesuatu yang prestise;

Kedelapan, walupun banyak barang yang diproduksi oleh UMKM juga untuk masyarakat kelas menengah dan atas (untuk yang terahir ini proposinya lebih kecil), terbukti secara umum bahwa pasar utama bagi UMKM adalah untuk barang-barang konsumsi sederhana dengan harga relatif murah, seperti pakaian jadi dengan desain sederhana, meubel dari kayu, bambu dan rotan, barang-barang lainnya dari kayu, alas kaki, dan alat-alat dapur dari almunium dan plastik.Barang-barang ini memenuhi kebutuhan sehari-hari dari masyarakat miskin atau berpendapatan rendah. Namun demikian, banyak juga UMKM yang membuat barang-barang non-konsumsi seperti peralatan-peralatan produksi,berbagai macam mesin sederhana dan/atau komponen-komponennya, bahan-bahan bangunan, dan barang- 
barang setengah jadi lainnya untuk kebutuhan kegiatankegiatan di banyak sektor seperti industri,konstruksi,pertanian, perdagangan,pariwisata, dan transportasi;

Kesembilan, sebagai bagian dari dinamikanya, banyak juga UMKM (khususnya UK dan UM) yang mampu meningkatkan produktivitasnya melalui investasi dan perubahan teknologi;walaupun negara berbeda mungkin punya pengalaman berbeda dalam hal ini,tergantung pada banyak faktor. Faktorfaktor tersebut bisa termasuk tingkat pembangunan ekonomi pada umumnya dan pembangunan sektor terkait pada khususnya; akses ke faktorfaktor penentu produktivitas paling penting, khususnya modal, teknologi atau pengetahuan dan SDM; dan kebijakan-kebijakan pemerintah yang mendukung keterkaitan-keterkaitan produksi antara UMKM dan UB, termasuk dengan perusahaan-perusahaan asing/berbasis penanaman modal asing); dan

Kesepuluh, seperti sering dikatakan di dalam literatur,satu keunggulan dari UMKM adalah terhadap pesaingnya (UB). UMKM sangat baik dan dapat berkamuplase dalam menghadapi kondisi apapun, teruji pada saat keadaan krisi ekonomi finansial melanda di seluruh dunia termasuk Indonesai. Kelompok usaha ini sangat stabil menghadapi keadaan global tersebut, di lain pihak atau di sektor industri yang menghadapi perubahan-perubahan kondisi pasar yang cepat sulit bertahan dan akhirnya gulung tikar saat krisis ekonomi 1997/98, namun UMKM dapat bertahan dan meraih keuntungan dari hal tersebut ${ }^{6}$.

\section{Kelemahan yang Dihadapi Oleh UMKM}

Mengulang kembali bahwa UMKM adalah salah satu penyumbang pertumbuhan ekonomi nasional yang tercermin dalam peningkatan Produk Domestik Bruto (PDB) merupakan peran dari Usaha Kecil dan Menengah. Grafik pertumbuhan dapat diamati melalui data Kementrian Koperasi dan Usaha Kecil dan Menengah dengan perkembangan pada Tahun 1997 tercatat sebesar 62,71 persen dan pada Tahun 2002 kontribusinya meningkat menjadi 63,89 persen.

Pada Tahun 2002 tercatat sebanyak 38,7 juta dan pada Tahun 2004 sebanyak 42,4 juta unit usaha. Peningkatan jumlah unit usaha ini juga diikuti dengan kenaikan jumlah tenaga kerja disektor UMKM. Pada Tahun 2004 jumlah pekerja di sektor UMKM tercatat hampir 80 juta orang, dari jumlah tersebut sebanyak 70,3 juta diantaranya bekerja disektor usaha kecil

6 Tulus Tambunan.DAMPAK DARI KEBIJAKAN"SATU PERSEN"PAJAK PADA UMKM.Jurnal Vol.8.Hal:1-20.2013 
dan sisanya disektor usaha menengah. Kendati demikian, kondisi UMKM tetap rawan karena keterbatasan akses terhadap dunia perbankkan, pasar bebas yang mulai dibuka,serta terbatasnya kebijakan yang mendukung sektor usaha kecil.

\section{Kelemahan Faktor Internal}

Tidak berkembangnya UMKM disebabkan oleh minimnya modal, inovasi teknologi, sumber daya yang handal dan Minimnya Jaringan bisnis yang dibangun. Penjabaranya adalah sebagai berikut;

1) Minimnya modal

Keberadaan capital(modal) merupakan fakor utama dalam pengembangan usaha. Minimnya modal yang dimiliki oleh UMKM berdampak pada sulitnya mengembankan usaha yang berkelanjutan. Pada umumnya UMKM dimiliki oleh perorangan atau perusahaan tertutup. Modal yang diandalkan adalah milik pribadi dengan jumlah yang terbatas,sedangkan kalaupun ada tambahan dana investasi berasal dari kredit perbankkan atau lembaga keuangan.

Namun, pada kenyataanya untuk memproleh tambahan modal meluli kredit dunia perbankkan harus memiliki jaminan dan angapan dimasyarakat proses yang lalui sangat berbelit-belit. Urusan yang panjang tersbut mengakibatkan UMKM mengurungkan niat untuk melakukan kredit dana pinjaman. Akhirnya, Solusi yang dilakukan oleh UKM untuk mencari pinjaman kredit modal melalui lembaga non formal atau rentenir dengan bunga yang sangat tinggi. Inilah yang akhirnya mematikan usaha UMKM untuk berkembang.

2) Inovasi teknologi

Kelemahan UMKM selanjutnya adalah minimnya varian produk yang dihasilkan dimiliki. Kejenuhan pasar terhadap produk yang ditawarkan oleh UKM adalah jenis varian produk yang tidak beragam, inovasi dan teknologi yang ketinggalan. Disinilah akhirnya UMKM akan mati usahanya tidak berkembang.

3) Sumber daya manusia yang handal

Sebagian besar usaha kecil tumbuh secara tradisional dan merupakan usaha keluarga yang turun temurun. Keterbatasan SDM usaha kecil baik dari segi pendidikan formal maupun pengetahuan dan keterampilannya sangat berpengaruh terhadap manajemen pengelolaan usahanya, sehingga usaha tersebut sulit untuk berkembang dengan optimal. Disamping itu dengan keterbatasan SDM-nya, unit usaha tersebut relatif sulit untuk 
mengadopsi perkembangan teknologi baru untuk meningkatkan daya saing produk yang dihasilkannya.

4) Minimnya Jaringan bisnis yang dibangun

Jaringan bisnis merupakan suatu hal yang penting dalam memasarkan produk. Keterbatasan komunikasi dalam kegiatan bisnis berakitbat kepada minimnya jaringan bisnis yang bisa dibangun. Maka produk UMKM akan sulit masuk kepasar dan berasaing dengan produk-produk impor yang memiliki jaringan bisnis yang luas. Memang pada umumnya UKM dibagun dari unit usaha keluarga, mempunyai jaringan bisnis yang sangat terbatas dan kemampuan menganalisis peluang pasar yang sangat rendah. Akhirnya yang terjadi produk yang dihasilkan dalam jumlah sangat terbatas dan mempunyai kualitas yang kurang kompetitif. Solusinya adalah mengusai pasar dengan memperbanya relasi atau membuka lebar-lebar pintu untuk hubungan jaringan bisnis.

\section{Kelemahan Faktor Eksternal}

Kelemahan faktor ini bisa dilihar dari beberapa indikator yang terjadi diantaranya;

1. Pemberlakuan perdagangan bebas

Penetapan perdaganan bebas meluli AFTA yang berjalan di wilayah Asia Tenggara dan telah menjalar di wilayah Asia lainnya secara tidak langsung memaksa UKM untuk mampu hidup dan bertahan dari gembang terjangan produk-produk kompetitor yang masuk dari wilayah manapun. Kualifikasi produk penetapan standar produk mau tidak mau harus diterapkan oleh UMKM agar produknya bisa bertahan dan bersaing di pasar. Mulai dari pemberlakuan efisiensi\&efektifitas produksi,serta menghasilkan produk dengan sertifikat yang ditetapkan oleh global yaitu ISO dan memperhatikan isu Hak Asasi Manusia sebagai bagian dari tenaga kerja. Sebab isu HAM ini sering dipergunakan untuk menganjal produk UMKM agar mampu bersaing dikancah global.

2) Terbatasnya akses market

Penekanan dari poin diatas bahwa memang akses market akan menyebabkan produk yang dihasilkan secara kompetitif baik di pasar domestik dan global tidak mampu bersaing. Bersaing dalam pasar bebas UMKM sulit mengembangkan sayap untuk bisa berkompetitif. Sedangkan sudah kita rasakan AFTA ada didepan mata tahun 2003 sudah terjadi. Tahun 2020 APEC dan AFTA akan berimplikasi luas terhadap dunia usaha khususnya UMKM untuk dapat bersaing berdagang secara bebas. 
3) Terbatasnya Sarana dan Prasarana Usaha

Ketersedian sarana dan prasarana usahan merupakan salah satu pendukun UKM untuk dapat berkompetitif. Jika terjadi kesulitan dalam mendapatkan sarana dan prasarana berkaitan dengan kemajuan dunia informasi produk yang ditawarkan pasti mengalami ketinggalan dengan pesaing. yang berhubungan dengan kemajuan ilmu pengetahuan dan teknologi, menyebabkan sarana dan prasarana yang mereka miliki juga tidak cepat berkembang dan kurang mendukung kemajuan usahanya sebagaimana yang diharapkan ${ }^{7}$.

\section{Peran UMKM Bagi Perubahan}

Peran UMKM dalam pembangunan baik ditingkat basis atau wilayah desa/kelurahan hingga Nasional dapat di lihat dari beberapa indikator. Pertama, keterlibatan UMKM terhadap pembentukan pendapatan per kapita. Kedua, keterlibatan UMKM dalam pembentukan PDRB. Ketiga, keterlibatan UMKM dalam pembentukan pertumbuhan ekonomi daerah (growth). Dalam kaitan ini dari sisi permintaan (demand-side effect) peningkatan pendapatan per kapita, PDRB, dan pertumbuhan ekonomi dapat memunculkan dampak positif dan negatif (positive-negative demand-side effect) terhadap perkembangan UMKM.

Dampak positifnya dengan keberadaan UMKM adalah peningkatan pendapatan perkapita dan PDRB masyarakat, maka permintaan terhadap produk-produk UMKM akan meningkat. Peningkatan permintaan ini akan membuka kesempatan kerja dan peluang untuk membuka/menambah usaha kecil baru. Pengaruh positif ini juga bisa dirasakan oleh UMKM yang bisa memenuhi perubahan selera kebutuhan konsumen kearah mengkonsumsi produk yang lebih sophisticated sebagai akibat meningkatnya pendapatan masyarakat. Kondisi ini menunjukkan bahwa peran UMKM dalam pembangunan mengikuti Tesis Flexible Specialization.

Sedangkan, dampak negatifnya kenyataan menunjukkan bahwa UMKM adalah industri yang hanya mampu membuat produk yang bersifat inferior. Sementara masyarakat dengan pendapatan tinggi lebih menyukai produk-produk yang lebih sophisticated yang biasa dihasilkan oleh usaha menengah/besar. Dengan demikian jika UMKM tidak bisa

\footnotetext{
7 Hafsah, Mohammad Jafar.2004.Upaya Pengembangan Usaha Kecil dan Menengah (UKM).Artikel $\quad$ Infokap.NOmor $\quad 25 \quad$ Tahun $\quad$ XX (http://www.jurnal.smecda.com/index.php/infokop/article/view/60/57) (di unduh 16 Nov 2016)
} 
menghasilkan produk yang lebih sophisticated maka akan kalah bersaing dengan usaha menengah/besar. Kondisi ini menunjukkan bahwa peran UMKM dalam pembangunan mengikuti Teori Klasik. Sebaliknya dari sisi penawaran (supply-side effect) peningkatan pendapatan per kapita, PDRB, dan pertumbuhan ekonomi juga dapat memunculkan dampak positif dan negatif (positive-negative supply-side effect) terhadap perkembangan UMKM.

Dampak positifnya, seperti jika pendapatan perkapita masyarakat, misalnya di sektor pertanian meningkat yang mencerminkan produktifitas tenaga kerja di sektor tersebut tinggi, maka suplai tenaga kerja sektor industri kecil akan meningkat. Kondisi ini bisa terjadi karena dengan pendapatan yang tinggi di sektor pertanian maka petani dapat mengurangi sedikit waktu mereka bertani, tanpa merugikan jumlah pendapatan mereka secara berarti, dan oleh karena itu mereka memiliki waktu untuk berproduksi di sektor industri kecil baik sebagai tenaga kerja atau membuka usaha kecil sendiri. Ini artinya, bahwa petani denagn penghasilan tinggi memiliki kesempatan (waktu dan investasi) untuk melakukan kegiatan di luar pertanian dengan membuka usaha kecil sendiri. Dengan demikian terjadi penawaran tenaga kerja dan wira usaha untuk membuka usaha kecil baru. Kondisi ini menunjukkan bahwa peran UMKM dalam pembangunan mengikuti Tesis Flexible Speciali-zation.

Dampak negatifnya adalah jika pendapatan perkapita masyarakat di sektor pertanian atau di industri menengah/besar tersebut tinggi, yang merefleksikan terbukanya kesempatan kerja yang lebih baik di sektor tersebut, maka suplai tenaga dan wira usaha ke sektor industri kecil akan berkurang. Atau banyak pekerja dan pengusaha berpindah profesi ke sektor pertanian dan industri menengah/besar.Kondisi ini menunjukkan bahwa peran UMKM dalam pembangunan mengikuti Teori Klasik ${ }^{8}$.

\section{Peraturan Pemerintah Mendukung Perkembangan UMKM}

Undang-undang No. 22 Tahun 1999 ini membuka peluang bagi UMKM agar bisa berkembang. Undang-undang No. 22 Tahun 1999 tentang Otonomi Daerah, kewenangan daerah mempunyai otonomi untuk mengatur dan mengurus masyarakat setempat.Namun, kenyataan yang terjadi UMKM mengalami kondisi buruk dengan tingginya pajak-pajak yang dibebankan dan aturan yang bukan mempermudah tetapi mempersulit perkembangan

\footnotetext{
8 Ahmad Rifa'i.PERAN UMKM DALAM PEMBANGUNAN DAERAH:FAKTA DI PROVINSI LAMPUNG.Jurnal Ilmu Administrasi Publik dan Pembangunan,Vol.1,No(2),Hal:133-143,2010
} 
UMKM. Dengan hal akan membahayakan bagi keberlangsungan kondisi UMKM menurunnya daya saing dan minimnya modal pendukung ${ }^{9}$.

Selanjutnya, Pemerintah mengeluarkan Paket Kebijakan Ekonomi Tahap VII di Istana Kepresidenan, Jakarta. Isi paket kebijakan tersebut adalah mempermudah sektor usaha dalam memperoleh pinjaman modal pembankkan dan mempercepat urusan penerbitan sertifikat tanah, ini merupakan salah satu dukungan dalam bentuk kebijakan untuk mengembangkan UMKM. Inilah strategi kebijakan ekonomi menurut Menteri Koordinator Bidang Perekonomian Darmin Nasution, merupakan fokus utama dalam memicu kontraksi perekonomian baik secara makro dan mikro ${ }^{10}$.

Definisi kebijakan paket VII ini adalah mempermudah kredit modal usaha bagi sektor UMKM untuk mendapat kucuran bantuan dari sektor perbankkan. Harapanya pergerakan ekonomi tidak hanya berkutat pada sektor industri bersekala besar saja namun ada celah yang bisa diisi oleh sektor usaha rumah tangga atau UMKM. Ini merupakan merupakan angin segar bagi tumbuh kembangnya UMKM yang tidak menjadi "anak tiri" lagi dalam pembiayaan ekonomi nasional.

Searah dengan kebijakan tersebut, pemerintah juga memberikan kemudahan bagi masyarakat untuk dapat mengurus setifikat tanah agar dapat dipergunakan untuk pengembangan usaha. Kebutuhan dalam pengurusan sertifiakt tanah diluar kawasan konservasi dan hutan lindung mencapai 90.663 .503 bidang, dimana yang telah bersetifikat baru mencapai 35.789 .766 bidang atau sekitar $40 \%$ dan sisanya $60 \%$ belum bersertifiat menurut data Menko Prekonomia. Ini merupakan gambaran bahwa jika aset tersebut segara disertifikat maka akan membawa dampak positif bagi pertumbuhan ekonomi.

Kedua indikator rencana kebijan ini bersinegri untuk mendorong reformasi struktur ekonomi. Pemerintah sebagai pemegang kebijakan fiskal dan sektor perbankkan dalam hal ini diwakili oleh BI pemegang kebijakan moneter bersama melakukan koordinasi untuk mendorong pertumbuhan ekonomi secara riil. Namun, secara implisit masyarakat didorong untuk berperan menciptakan UMKM baru agar kontraksi ekonomi bergerak khususnya diwilayah pedasaan/kelurahan yang merupakan basis keberadaan usaha tersebut ${ }^{11}$.

\footnotetext{
${ }^{9}$ Undang-undang No. 22 Tahun 1999

${ }^{10} \mathrm{http}: / /$ www.kemenkeu.go.id/kebijakanekonomi7 (di unduh 10 Nov 2016)

11 Kementrian Kopterasi Dan Usaha KEcil dan Menengah Republik Indonesia (http://www.depkop.go.id/berita-informasi/data-informasi/data-umkm/) (di unduh 16 Nov 2016)
} 
Undang-Undang No.20 Tahun 2008 yang telah disahkan oleh pemerintah menyatakan pengembangan UMKM meliputi memperluas iklan usaha yang kondusif bagi pengembangan UMKM, meningkatkan produktivitas dan daya saing UMKM,meningkatkan kapasitas SDM, meningkatkan citra UMKM dan mengembangkan sinergi peran serta masyarakat dan stake holder dalam pemberdayaan $\mathrm{UMKM}^{12}$.

Upaya meningkatkan kemampuan dan peran serta kelembagaan usaha kecil menengah dalam perekonomian nasional, maka pemberdayaan tersebut perlu dilakasanakan oleh pemerintah, pemerintah dunia, dunia usaha dan masyarakat secara menyeluruh.Untuk mengetahui faktor-faktor yang mempengaruhi produktivitas kerja usaha mikro kecil dan menengah (UMKM) ${ }^{13}$.Pemerintah di Tingakat wilayah Pedasaan harus memegang peranan penting dalam menghidupakan UMKM dan harus memberikan motivasi yang tidak hentihenti demi mengkontraksi ekonomi secara keseluruhan untuk bisa menjadikan keadaan lebih sejahtra kedepanya.

\section{Desa Wilayah Basis UMKM}

Perkataan desa berasal dari perkataan "sankrit" yang artinya tanah air, tanah asal, tanah kelahiran. Perkataan desa hanya dipakai didaerah Jawa,Madura, dan Bali. Sementara didaerah Sumatra Selatan disebut dengan Dusun. Di Maluku, perkataan desa disebut dengan istilah Dusun "dati". Di Acah disebut "Gampong" dan Meunasah buat daerah hukum yang paling bawah. Di Batak, Daerah hukum setingkat dengan desa diberi nama Kotauta atau huta dan lainnya. Desa atau sebut-sebutan lain yang sangat beragram di Indonesia, pada awalnya merupakan organisasi komunitas yang mempunyai batas-batas wilayah, dihuni oleh sejumlah penduduk, dan memiliki adat-istiadat untuk mengelola wilayahanya sendiri. Inilah yang disebut dengan self governing communiti ${ }^{14}$.

Sebutan desa sebagai kesatuan masyarakat hukum baru dikenal pada masa koloniel Belanda. Desa sebagai suatu kesatuan hukum dimana bertempat tinggal suatu masyarakat, yang berkuasa mengadakan pemerintahan sendiri desa terjadi dari hanya satu tempat

${ }^{12}$ Undang-Undang No.20 Tahun 2008

${ }^{13} \mathrm{Ni}$ Wayang Duti Ariani, dan A.A Ayu Suresmiathi D.PENGARUH KUALITAS TENAGA KERJA, BANTUAN MODAL USAHA DAN TEKNOLOGI TERHADAP PRODUKTIVITAS KERJA USAHA MIKRO KECIL DAN MENENGAH(UMKM) DI JIMBARAN. Jurnal EP Unud,Vol.2, No(2),Hal:102-107,2013.

14 Dody Eko Wijayanto.KEPALA DESA DENGAN BADAN PERMUSYAWARATAN DESA DALAM PEMBENTUKAN PERATURAN DESA.Jurnal Independen,Vol.2,,No(1),Hal:40-50 (diakses 25/12/2016) 
kediaman masyarkat saja ataupun terjadi dari satu induk desa dan beberapa tempat kediaman sebagian dari pada masyarakat hukum yang terpisah yang merupakan kesatuan-kesatuan tempat tinggal sendiri. Kesatuan-kesatuan mana dinamankan pedukuhan, ampean, kampong, cantilan berserta tanah pertanian, tanah perikanan, tanah perikanan darat(empang tambak dan sebagainya), tanah hutan dan tanah belukar. Besar desa itu berbeda-beda dipergununggan memiliki daerah yang sangat luas ditanah negare daerahnya biasanya kecil.

Dalam Undang-Udang No.32 Tahun 2004 tentang pemerintahan daerah menyebutkan bahwa desa disebut dengan nama lain adalah kesatuan masyarakat hukum yang memiliki batas-batas wilayah yuridisksi, berwenang untuk mengatur dan mengurus kepentingan masyarakat setempat berdsarkan asal-usul dan adat-istiadat setempat yang diakui dan dihormati dalam Sistem Pemerintahan NKRI ${ }^{15}$.

Berdasarkan penjelaskan diatas, secara tersirat bahwa desa merupakan wilayah dengan penduduk, adat istiadat secara communiti homogen dan memiliki kemiripan karakteritik pola pikir yang sama hingga mata pencaharian yang mampir sama atau homogen yaitu bidang pertanian. Desa memiliki kemadirian dalam tata kelola pemerintahan.

Akibat homogenya mata pencaharian tersebut yang otomatis jika keadaan pertanian mengalami musin "peceklek" atau gagal panen maka semua masyarakat mengalami kesulitan ekonomi. Ini yang mengakibatkan beberapa anggota masyarakat mulai menemukan suatu trobosan dengan merintis UMKM-UMKM sesuai dengan basis hasil pertanian yang dihasilkan.

Seperti yang banyak berkembang dan hampir sangat mudah ditanam oleh semua penduduk di pedesaan dan cepat menghasilkan nilai ekonomi diantaranya tanaman; singkong menghasilkan keripik singkong, getok, dan banyak lagi output yang bisa diproduksi dari tanaman ini. Sebenarnyan masih banyak lagi hasil pertanian yang bisa diolah menjadi makanan dengan nilai ekonomis tinggi yang bisa dijadikan produk rumahan dan berskala Nasional.

Ini merupakan momentup yang sangat strategis ketika setiap Desa dipimpin oleh individu-individu yang mau membangun dan mengembangkan wilayahnya dengan mengandalkan sumber daya dengan maksimal yang dimiliki. Maka yang terjadi adalah wilayahnya tersebut akan menjadi wilayah yang memiliki kader-kader wirausaha handal yang bisa menciptakan lapangan kerja dan menekan tingkat kemiskinan. Itu sebabnya basis

${ }^{15}$ Undang-Udang No.32 Tahun 2004 
UMKM berada di wilayah pedesaan yang merupakan wilayah yang menjadi induk untuk mengembangkan industri rumahan atau UMKM.

\section{Kepemimpinan Dalam Mengembangkan UMKM}

Kepemimpinan merupakan suatu proses yang dilakukan oleh seorang pemimpin dalam mempengaruhi sikap, perilaku dan nilai- nilai orang lain dalam hal ini warga yang dibina. Kepemimpinan yang baik akan mampu memberikan hubungan timbal balik yang selaras dan harmonis dalam menghasilkan tujuan bersama menuju kejenjang yang lebih tinggi, sesuai dengan keinginan yang akan dicapainya.

Upaya mempengaruhi kegiatan warganya dalam hal ini anggota bimbingan (bawahan) melalui proses komunikasi untuk mencapai tujuan tertentu. Pada prinsipnya seorang pimpinan harus memiliki konsep dan kemampuan individual yang kuat yang mampu memberikan arah yang jelas bagi tercapainya tujuan melalui pendelegasian tugas dan wewenang kepada bawahanya atau warganya .Sehingga dapat diartikan bahwa kepemimpinan merupakan suatu pertumbuhan alami dari orang - orang yang berserikat, untuk suatu tujuan dalam suatu kelompok. Kepemimpinan yang dimaksud sebagai kemampuan seseorang atau pemimpin, untuk mempengaruhi perilaku oraang lain menurut keinginan-keinginannya dalam suatu keadaan tertentu. Sehingga totalitas, apa yang diinginkan atau diperintah akan dilaksanakan secara absolut tanpa adanya penolakan ataupun argumentasi.

Pemimpin harus memiliki sifat untuk dapat mengendalikan anggota warganya yang dipimpin diantaranya: kecerdasan baik keilmuan formal maupun spritual guna mengendalikan anggota yang dipimpinnya. Pemimpin haru memiliki sifat kedewasaan dan keluasan hubungan sosial, pemimpin cenderung menjadi matang dan mempunyai perhatian yang luas terhadap aktivitas-aktivitas sosial. Sehingga dapat menciptakan suasana menghargai dan dihargai. Pemimpin harus dapat motivasi diri dan mendorongan untuk anggotanya atau warganya berprestasi, para pemimpin secara relative mempunyai dorongan motivasi yang kuat untuk berprestasi. Mereka bekerja berusaha mendapatkan penghargaan yang intrinsik dibandingkan dengan ekstrinsik. Akhirnya pemimpin harus memiliki sikap dan hubungan kemanusiaan, pemimpin-pemimpin yang berhasil mau mengakui harga diri dan kekuatan para pengikutnya dan mampu berpihak kepadanya ${ }^{16}$.

${ }^{16}$ Bangun Prajadi Cipto Utomo.PENGARUH KEPEMIMPINAN, MOTIVASI KINERJA, 
Berdasarkan peraturan NO.34 Tahun 2000 tentang tata kerja pemerintahan desa adalah kegiatan pemerintahan yang dilaksanakan oleh pemerintah desa dan Badan Perwakilan Desa. Dari pengertian tersebut dapat diambil suatu pemahaman bahwa pada dasarnya ada 2 lembaga strategis yang menjalankan pemerintahan desa, yakni pemerintah desa dan badan perwakilan desa. Yang dimaksud dengan pemerintah desa adalah kepala desa dan prangkat $\operatorname{desa}^{12}$.

Jadi Kepala desa merupakan alat pemerintah desa yang memimpin penyelengaraan pemerintah desa dan berkedudukan sejajar dengan Badan Permusyawaratan Desa. Sedangkan Perangkat desa adalah usur yang membantu kepala desa dalam melaksanakan tugas dan fungsinya.

Reformasi Pemerintahan di Tingkat wilayah Desa bahwa desa memiliki dana alokasi yang dapat dipergunakan untuk mengembangkan wilayahnya mulai dari infrastruktur keras hingga lunak. Infrastrukrut keras berupa; jalan, jembatan tempat ibada dan ruang terbuka bagi kegiatan sosial masyrakat, infrastruktur lunak membangun jaringan internet yang bisa meningkatkan akses informasi untuk menerima keilmuan baru yang membuka wawasan berfikir. Dana tersebut dipegang dan dikendalikan oleh Kepala desan dan perangkatnya. Otonomi ini mendorong pemberdayaan bagi kesejahtraan masyakatnya. Tujuanya adalah menekan angka penganguran dan tingkat kemiskinan yang memang banyak berdiam diwilayah pedesaan.

Dibutuhkan pemimpin yang memiliki jiwa membangun untuk mengembangkan wilayahnya. Sesuai dengan sifat kepemipinan diatas yaitu kecerdasan intelektual dalam membaca situasi yang diperlukan dalam bertindak demi kesejahtraan masyarakat. UMKM yang berada pada wilayahnya harus dikembangkan dengan pembinaan mulai dari pendanaan hingga pendidikan kewirausahaan untuk menciptakan lapangan kerja baru yang otomatis akan memajukan wilayah yang dipimpinya. Ini memang tidak mudah namun dibutuhkan sifat-sifat kepemimpinan dan harus berkoordinasi dengan pihak-pihak yang terkait dan memahami keadaan yang terjadi saat ini.

DISIPLIN KERJA DAN LINGKUNGAN KERJA TERHADAP KINERJA KARYAWAN DAN DOSEN STIMIK DUTA BANGSA SURAKARTA.Artikel-STIMIK DUTA BANGSA SURAKARTA.Hal:1-12(diunduh 23 Desember 2016). 


\section{Kesimpulan}

Pemerintah telah banyak melakukan kebijakan demi melindungi UMKM agar tetap berkembang. Kebijakan yang diambil muali dari hulu hingga hilir. Secara umum pemerintah membuat kebijakan untuk mempercepat pertumbuhan ekonomi yang terkait langsung dengan UMKM untuk dapat meningkatkan kesejahtraan masyarakat di desa. Pembinaan harus selalu dipantau oleh Pemerintah dalam hal ini Tingkat Desa sebab yang bersentuhan langsung dengan UMKM sebagai basis usaha untuk meningkatkan kesejahtraan masyarkaat.

Ditinjau dari nilai manfaat bahwa program pinjaman modal kredit bergulir yang didistribusikan oleh Pemerintah ternyata memiliki nilai manfaat yang sangat berarti untuk memacu pelaku usaha kecil dan menengah dalam mengembangkan kemampuan usaha mikro menjadi usaha kecil, dan dari usaha kecil menjadi usaha yang tangguh dan mandiri bahkan dapat berkembang menjadi usaha menengah dan usaha besar, sekalugus mampu meningkatkan daya saing di segment pasar.

Kecerdasan intelektural dan kedewasaan seorang pemimpin Desa diharapkan mampu meramu kewengan yang dimiliki untuk dapat mengelola wilayahnya menjadi lebih mandiri dan lebih sejahtra kedepannya. Hal ini dengan diberikan wewengan pengelolaan Dana Desa untuk pengembangan wilayah Desa melalui UMKM yang telah digariskan oleh pemerintah dalam mengentaskan kemiskinan dan menurunkan pengangguran atau penyerapan tenaga kerja.

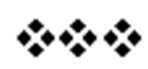

\section{Daftar Pustaka}

Siregar, Hermanto., dan Wahyuniarti,Dwi. Dampak Pertumbuhan Ekonomi Terhadap Penurunan Jumlah Penduduk Miskin. (Artikel Ekonomi Lingkungan IPB,HAL:23-40, 2008).

Data BPS Indonesia dalam angka 2010-2011.

Rifa'i, Bachtiar. Efektivitas pemberdayaan usaha mikro kecil dan menengah (umkm) krupuk ikan dalam program pengembangan labsite pemberdayaan masyarakat desa kedung rejo kecamatan jabon kabupaten sidoarjo. (Jurnal Kebijakan dan Manajemen Publik.Vol.1,No(1),Hal:130-136,2013).

Purwanti , Endang. Pengaruh Karakteristik Wirausaha, Modal Usaha, Strategi Pemasaran Terhadap Perkembangan Umkm Di Desa Dayaan Dan Kalilondo Salatiga. (Jurnal Among Makarti.Vol.5.No(9).Hal:13-28, 2012). 
Tambunan ,Tulus. Dampak Dari Kebijakan "Satu Persen" Pajak Pada Umkm. (Jurnal Vol.8.Hal:1-20.2013).

Hafsah, Mohammad Jafar.Upaya Pengembangan Usaha Kecil dan Menengah (UKM).Artikel $\begin{array}{lllll}\text { Infokap. } & \text { Nomor } & 25 & \text { Tahun } & \text { XX, }\end{array}$ (http://www.jurnal.smecda.com/index.php/infokop/article/view/60/57) (di unduh 16 Nov 2016)

Rifa'i ,Ahmad. Peran Umkm Dalam Pembangunan Daerah :Fakta Di Provinsi Lampung. (Jurnal Ilmu Administrasi Publik dan Pembangunan,Vol.1,No(2),Hal:133-143,2010).

Undang-undang No. 22 Tahun 1999

http://www.kemenkeu.go.id/kebijakanekonomi7 (di unduh 10 Nov 2016)

Kementrian Koperasi Dan Usaha Kecil dan Menengah Republik Indonesia (http://www.depkop.go.id/berita-informasi/data-informasi/data-umkm/) (diunduh 16 Nov 2016).

Undang-Undang No.20 Tahun 2008

Ariani ,Ni Wayang Duti., dan Suresmiathi D, A.A Ayu. Pengaruh Kualitas Tenaga Kerja, Bantuan Modal Usaha Dan Teknologi Terhadap Produktivitas Kerja Usaha Mikro Kecil Dan Menengah (Umkm) di Jimbaran.(Jurnal EP Unud,Vol.2, No(2),Hal:102107,2013).

Wijayanto,Dody Eko. Kepala Desa Dengan Badan Permusyawaratan Desa Dalam Pembentukan Peraturan Desa. (Jurnal Independen,Vol.2,,No(1), Hal:40-50 (diakses 25/12/2016))

Undang-Udang No.32 Tahun 2004

Utomo ,Bangun Prajadi Cipto. Pengaruh kepemimpinan, motivasi kinerja, disiplin kerja dan lingkungan kerja terhadap kinerja karyawan dan dosen stimik duta bangsa surakarta.(artikel-stimik duta bangsa Surakarta .Hal:1-12(diunduh 23 Desember 2016)). 